\title{
Loan Repayment Performance of Oromia Credit and Saving Share Company Borrowers and Its Determinants in Ada'A Barga District, Oromia National Regional State, Ethiopia
}

\author{
Mammo Agama ${ }^{1 *} \quad$ Getachew Gobena ${ }^{2} \quad$ Milkessa Asfaw ${ }^{3}$ \\ 1.Department of Business Administration, College of Business and Economics, Rift Valley University, Ethiopia \\ 2. Department of Business Management, College of Business and Economics, Rift University, Ethiopia \\ 3. Department of Agricultural Economics, College of Agriculture and Natural Resources, Ethiopia
}

\begin{abstract}
In developing countries like Ethiopia Microfinance institutions are playing an essential role in poverty reduction; to provide the provision of micro-credit, savings, and other services to the poor that are excluded by the commercial banks for collateral and other reasons. However, there is a loan repayment problem, which discourages rural finance organizations from promoting and extending credit. Therefore, this study focuses on identifying the factors affecting the loan repayment performance of OCSSC borrowers in Ada'a Barga district, Oromia National Regional State, Ethiopia. Purposive and random sampling technique was used to select 139 sampled respondents. Both primary and secondary data sources were used for this study. Descriptive statistics and t-test and chi-square test analyses were employed to compare defaulters and non-defaulters with the explanatory variables. Also, binary logit econometric model was used to examine the factors that affect credit repayment performance of the selected sampled household borrows of OCSSC. The result showed that out of 139 chosen respondents, 56 were defaulters and 83 were non-defaulters. A total of twelve explanatory variables were included in the empirical model and out of the total hypothesized explanatory variables involved in the model, age, educational level, celebration of social ceremony and participation in off/non-farm activities were positively and statistically significantly affected loan repayment performance at $1 \%$ significance level. Moreover, livestock ownership positively affected loan repayment at 5\% 1\% significance level. On the contrary purpose of borrowing and family size was negatively and significantly affected loan repayment performance at $5 \%$ and $10 \%$ significance level. Therefore, the study recommended that the identified significant variables have to be a springboard for further interventions by financial institutions, stakeholders and policymakers to come with a breakthrough to significantly decrease or even avoid defaulting problems.,
\end{abstract}

Keywords: Binary logit; defaulters; loan repayment; non-defaulters; OCSSC

DOI: $10.7176 /$ RJFA/12-9-05

Publication date:May $31^{\text {st }} 2021$

\section{INTRODUCTION}

Microfinance institutions (MFIs) have been established to provide loan and other services to the poor and lowerincome groups to help them to alleviate their poverty and become self-employed by making their business activities. This is in contrast to formal banks, which provide loans to relatively better off members of society based on collateral. Microfinance can be considered as a development tool that provides financial as well as social intermediation involving citizens groups to voice their ambitions, raise concerns for consideration by policymakers, and develop their self-confidence (Chliova et al., 2015). In developing countries like Ethiopia, where the farming system is at its traditional level, and the saving and credit financial sectors are at their infant stage, the role of a financial industry is significant in terms of their employment generation capacity, quick production response, adaptation to weak infrastructure, use of local resources and as a means of developing indigenous entrepreneurial and managerial skills for a sustained growth need (Tura, 2016).

The primary objective of MFIs is to provide financial services credit and saving to the poor to relieve financial constraints and help alleviate poverty. Each MFI tries to maximize its repayment performance, whether it is profit oriented or not. One indicator of effective MFIs is the loan repayment performance of the borrowers (Fikirte, 2011). They enable the MFI to cut the interest rate it charges to the borrowers, thus reducing the financial cost of credit and allowing more borrowers to have access to it.

Smallholder farmers face a severe shortage of financial resources to purchase productive agricultural inputs. The prices of inputs rise very rapidly every year. Consequently, the hope of the subsistence farmers on financial institutions for credit has become substantially higher in recent times (Million et al., 2012). Development and adoption of new agricultural technologies and the use of credit facilities are vital for rapid growth in agricultural productivity. However, with the introduction of new production technologies, the financial needs of farmers increased by many-fold (Ayalew and Lemma, 2013).

There is no doubt about the crucial roles of credit in economic development. But the increasing default rate is one of the significant problems of lending institutions (Mohammad, 2009). Loan default problem has been 
heartbreak as it leads to a system failure to implement appropriate lending strategies and credible credit policies. So, improving repayment rates helps to reduce the dependence on subsidies of the MFIs, which would enhance sustainability. It is also argued that high repayment rates reflect the adequacy of MFIs' services to clients' needs. They limit the incidence of cross subvention across the borrowers. Finally, yet importantly, repayment performance is a crucial variable for donors and international findings agencies on which many MFIs still depend for their access to funds (Lewis, 2018).

It is evident that many rural credit systems have sustained heavy losses because of weak loan collection. And yet a lot more has been dependent on government subsidy to financially cover the damages they faced through loan default (Firafis, 2014). The loan default problem has had adverse effects leading to systems failure in the implementation of appropriate lending strategies and credible credit policies. So, examining repayment performance is essential since if borrowers do not repay, then there may not be sufficient funds to ensure that the liquidity position of the MFI is maintained. When there is a loss in the MFI liquidity due to high levels of no repayment, the cyclical flow of funds between the MFI and the borrowers will be interrupted (Nawai \& Sharriff, 2012).

According to Simkovic (2013) lending risk was the possibility that the borrowers may not pay the loan on time with interest and the market risks include lower prices for borrowers' products and services, which could directly affect their ability or willingness to repay an outstanding loan. Each MFI tries to maximize its repayment performance, whether it is profit oriented or not. One indicator of effective MFIs is the loan repayment performance of the borrowers (Sengupta and Aubuchon, 2008). High repayment rates are associated with benefits both for the MFI and the borrowers (Godquin, 2004). If there is high repayment rate, the relationship between the MFI and their client will be useful, as Bond and Rai (2009) argue that high repayment rate helps to obtain the next higher amount of loan and other financial services.

Most MFIs in Ethiopia are experiencing default problems as can be observed from their declining repayment rates (Abafita, 2003). The reasons for the low performance of loan repayment in rural borrowers are taking of loan without considering their capacity of repaying the loan and unwillingness to repay the loan (Girma, 2018).To maintain the sustainability of those MFIs, examining factors that affect loan repayment is essential, because if borrowers do not repay, then there may not be sufficient funds to ensure that the liquidity position of the MFI is maintained. When there is a loss in the MFI liquidity due to high levels of non-repayment, the cyclical flow of funds between the MFI and the borrowers will be interrupted (Nawai and Shariff, 2013).Different approaches have been employed in alleviating poverty; one is the provision of credit. Provision of credit to the poor takes advantage of economic opportunities to increase their level of output; hence move out of poverty for targeted poor. Credit is considered to be an essential input to increase productivity (Nawai and Shariff, 2013).

It is essential that borrowed funds be invested for productive purposes, and the additional incomes generated, be used to repay loans to sustain and make the production process and credit institutions viable. Reduced loan repayment in developing countries has become a significant problem in agricultural credit administration, especially by smallholders who have limited collateral capabilities (Sileshi et al., 2012). The loan default problem has had destructive effects leading to systems failure in the implementation of appropriate lending strategies and credible credit policies. Therefore, a thorough investigation of various aspects of loan defaulting is essential for both the policymakers and the lending institutions. Therefore, identifying the socioeconomic, demographic and institutional factors that affect repayment performance is a critical issue in microfinance in providing sustainable financial services (Kefeni, 2018). Therefore, this study was aimed at identifying and examining factors affecting loan repayment performance of OCSSC borrowers of Ada'a Barga district.

\section{RESEARCH METHODOLOGY \\ Description of the Study Area}

Ada'a Berga is one of the woredas in the Oromia national regional state of Ethiopia. Part of the Mirab Shewa Zone, Ada'a Berga is bordered on the south by Walmara, on the southwest by Ejerie, on the west by Meta Robi, and on the north and east by the Muger River which separates it from the Semien Shewa Zone. Towns in Ada'a Berga include Enchini, Muger and Reji. High points in this woreda include Mount Fota (3235 meters). Rivers include the Berga, the main tributary of the upper Awash River. Although coffee is an important cash crop of this woreda, less than 20 square kilometers are planted with this crop. The 2007 national census reported a total population for this woreda of 120,654, of whom 60,366 were men and 60,288 were women; 15,940 or $13.21 \%$ of its population were urban dwellers. The majority of the inhabitants are followers of Christianity, with $88.54 \%$ while $5.7 \%$ of the population practiced traditional beliefs, and $5.29 \%$ were protestant (CSA, 2005)

\section{Data Types, Sources and Collection Methods}

The study used both quantitative and qualitative types of data. Both primary and secondary data sources were 
employed. The primary data that focus on socioeconomic, institutional and demographic characteristics of borrowers were collected by using structured questionnaire from the borrowers of the sampled households. Secondary data was collected from articles, websites, reports and different published and unpublished materials. To support data collected by questionnaires, key informant discussion was made with branch manager.

\section{Sampling Technique and Sample Size Determination}

Ada'a Barga district has 37 kebeles, and the total credit user households in this district were about 6,200. Purposive and two stages random sampling techniques were employed to select the sample respondents. In the first stage, from the 37 credit users kebeles four kebeles (Maru Cobot, Bishaan Diimoo, Sire barga and Iluu warabboo) were selected purposively because of large number of borrowers in this district. In the first stage, households were stratified into credit users and non-credit users. Finally, 139 borrowers were selected by using simple random sampling technique based on probability proportional to size of credit users in each of the four selected kebeles. To obtain a representative sample size, the study employed the sample size determination formula given by Yamane (1967) as follow (Equation 1):

$n=\frac{N}{1+N(e)^{2}}=\frac{1321}{1+1321(0.08)^{2}}=139-----------$ (1)

Where:

$\mathrm{n}=$ is sample size.

$\mathrm{N}=$ is total number of credit user households in the selected kebeles (1321)

$\mathrm{e}=$ is margin error $(8 \%)$

Table 6: Distribution of credit users and sampled households in the selected kebeles

\begin{tabular}{lll}
\hline Name of kebeles & Total number of credit users & Sampled households \\
\hline Sire Barga & 375 & 39 \\
Iluu warabboo & 325 & 34 \\
Bishaan Diimoo & 300 & 32 \\
Maaruu Cobot & 321 & 33 \\
\hline Total & $\mathbf{1 , 3 2 1}$ & $\mathbf{1 3 9}$ \\
\hline
\end{tabular}

Source: Ada'a Barga District OCSSC branch (2020)

\section{Method of Data Analysis}

To address the objectives of the study, both descriptive and inferential statistics and econometric model were employed.

\section{Descriptive and inferential statistics}

Descriptive statistics such as percentages, frequencies, mean and standard deviation were used. In addition, inferential statistics like t-test and chi-square were employed to compare and contrast defaulters and nondefaulter respondents based on the selected explanatory variables.

\section{Econometric analysis}

Dichotomous discrete choice models (Logit and Probit) is used when the dependent variable is dummy that takes a value of zero or one, depending on whether or not a borrower has defaulted. This model assumes that individuals are faced with a choice between two alternatives and that the choice depends on identifiable characteristics (Pindyck and Rubinfeld, 1998). The main difference between the logit and probit model is on assumptions of probability distribution. The logit model assumes cumulative logistic probability distribution whereas the probit model assumes the cumulative normal probability function.

\section{Model specification}

Logit and Probit models are commonly used in studies involving qualitative choices. When the dependent variable is qualitative, the aim is to find the probability of happening of the event. The maximum likelihood (ML) estimation technique, than the ordinary least square (OLS) is a commonly used method in estimating the parameters that have discrete dependent variables. In this study, the logit model, one of the econometric models that use ML, to estimate the parameters of loan repayment performance will be applied. The reason why binary logit model is selected for this study over the probit model is because it has some advantage when sample size is small. The dependent variable in this study is binary, which takes the value zero if the borrowers were defaulters whereas one where the borrowers are non- defaulters. However, the explanatory variables can be either continuous or dummy. Loan repayment is, therefore, a non-continuous dependent variable that does not satisfy the key assumptions in the linear regression analysis. 
When the dependent variable to be modeled is limited in its range, using ordinary least squares (OLS) may result in biased and inconsistent parameter estimates (Cameron and Trivedi, 2005). Hosmer and Lemeshew (1999) agree with the advantage of logistic distribution in the analysis of dichotomous outcome. Therefore, this study employed logit model.

Assume that there exists a latent (unobserved) variable such that:

$y_{i}^{*}=\beta_{i X_{i}}+\varepsilon_{i}$

Where $\boldsymbol{y}_{i}^{*}$ a vector of the latent variable that is not observed for values less than zero and greater than one.

$$
y_{i}=\left\{\begin{array}{l}
1 \text { if } y_{i} *>0 \\
0 \text { if } y_{i} * \leq 0
\end{array}\right.
$$

Where:

$\mathrm{y}_{\mathrm{i}}=$ is a binary variable for the probability of borrowers loan repayment performance, with:

$\mathrm{y}=$ which is 0 if the borrower is a defaulter and 1 if the borrower is non-defaulter.

$\beta=$ the unknown parameters that reflecting the impact of change in variable $X$,

$\mathrm{x}_{\mathrm{i}}=$ explanatory variables that determine the dependent variable.

$\varepsilon_{\mathrm{i}}=$ is the error terms.

$\mathrm{i}=1,2,3 \ldots \mathrm{n}$, represents the number of observations.

The specification would provide with a Cumulative Density Function (CDF). In practice, there are two choices of distribution; such as standard normal and standard logistic CDF. The logit model assumes cumulative logistic probability distribution whereas the probit model is associated with the cumulative normal probability function. Maddala, (1983) reported that the normal and logistic CDFs are very close in the mid-range, but the logistic function has slightly fatter tails than the normal function, (Hosmer and Lemeshew, 1989) agree with the advantage of logistic distribution in the analysis of dichotomous outcome. Therefore, the logistic model will be selected for this study. The cumulative logistic probability is specified as follows (Verbeek, 2008).

$\mathrm{P}_{\mathrm{i}}=\mathrm{F}(\mathrm{Zi})=\mathrm{F}\left(\alpha+\Sigma \beta i X i=\frac{1}{1+e^{-Z i}}\right.$

According to Hosmer and Lemeshew ,(1989) pointed out that the logistic model could be written in terms of the odds and $\log$ of odds, which enables one to understand the interpretation of the coefficients. The odds ratio implies the ratio of the probability $(\mathrm{Pi})$ that an individual would choose an alternative to the likelihood (1-Pi) that he/she would not accept it.

Therefore $\frac{P i}{1-P i}=\frac{1+e^{Z i}}{1+e^{-Z i}}$

Taking the natural logarithm is:

$\mathrm{Y}_{\mathrm{i}}=\ln \left(\frac{P i}{1-P i}\right)=\alpha+\beta i X i+\beta 1 X 1+\beta 2 X 2+---\beta m X m$

If the error term $(\boldsymbol{\varepsilon})$ is taken in to account, the logit model becomes:

$\mathrm{Y}_{\mathrm{i}}=\alpha+\sum_{t=1}^{m} \beta i X i+\varepsilon i$

Where,

$\mathrm{Y}_{\mathrm{i}}=$ is dependent variable

$\alpha=$ is constant term

$\beta_{\mathrm{i}}=$ is coefficient of each independent variables

$\mathrm{X}_{\mathrm{i}}=$ is explanatory variables

$\varepsilon_{\mathrm{i}}=$ error/stochastic term

The unknown parameters $\beta$ 's are estimated by likelihood function.

\section{RESULTS AND DISCUSSION}

Loan Repayment Status of the Borrowers

The loan repayment statuses of borrowers of the respondents were taken as the primary way to group the borrowers into defaulters and non-defaulters. Accordingly, in the study area $83(59.71 \%)$ of the sample respondents were non-defaulters who were repaying the loan on time while $40.29 \%$ were defaulters (Fig. 1). 
Figure 5: Loan Repayment status of respondents

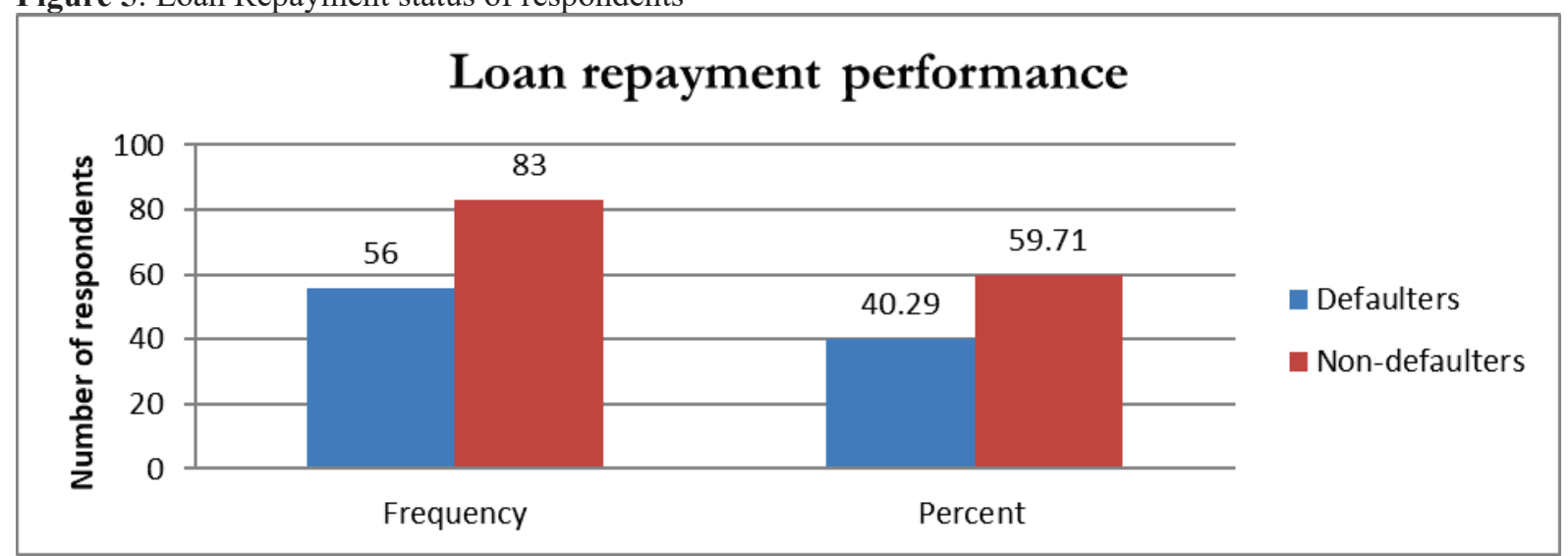

Source: Computed from survey data (2020)

\section{Descriptive Results}

Descriptive statistics like mean, standard deviation, minimum and maximum were employed in order to summarize and describe the demographic, socio-economic and institutional characteristics of the respondents. Furthermore, t-test and chi-square test were employed to compare defaulters and non-defaulters in relation to the explanatory variables.

\section{Demographic characteristics among defaulters and non-defaulters}

Age: Age is one of the main factors which determine management experience of individuals. The average age of the total sampled households during the survey period, was about 38.12years (Table 2). This implies that most of the household heads were within their productive age. When we compare the average age of non-defaulters with defaulters in the study area it is 40.88 and 34.04years respectively which shows non-defaulter households are somewhat older than defaulter households. This helped them to accumulate better wealth and ability to repay their debt in time than defaulters. The t-test value shows there was significant mean difference between defaulters and non-defaulters based on their age at $1 \%$ significance level. Mean that there is significant mean age difference between defaulters and non-defaulters in the study area.

Table 7: Age of the respondents by repayment status

\begin{tabular}{lllll}
\hline Age & Defaulters (56) & Non-defaulters (83) & Total sample $(\mathrm{N}=139$ & t-value \\
\hline Mean & 34.04 & 40.88 & 38.12 & \\
Std. Dev. & 6.58 & 5.82 & 6.98 & $-6.451 * * *$ \\
Minimum & 24 & 30 & 24 & \\
Maximum & 45 & 67 & 67 & \\
\hline
\end{tabular}

*** Significant at $1 \%$ probability level

Source: Computed from survey data (2020)

Sex of household head: The sample was composed of both male and female-headed households, of the total sample household heads $58.27 \%$ were male household heads and $41.73 \%$ were female household heads. Also from the total of households $42.86 \%$ of the defaulters' and 40.96 of the non-defaulters were female households respectively and also $57.14 \%$ and $59.04 \%$ of the male households were defaulters and nondefaulters respectively, with regard to sex of household head were not statistically significant between two groups (table 3).

Table 8: Distribution of household head sex by repayment status

\begin{tabular}{llllllll}
\hline Sex & \multicolumn{2}{l}{ Defaulters $(56)$} & \multicolumn{2}{l}{ Non-defaulters $(83)$} & \multicolumn{2}{c}{ Total sample (139) } & \multirow{2}{*}{$\chi 2$-value } \\
\cline { 2 - 6 } & No. & $\%$ & No. & $\%$ & No. & $\%$ & \multirow{2}{*}{0.049} \\
\hline Male & 32 & 57.14 & 49 & 59.04 & 81 & 58.27 & \multirow{2}{*}{ Female } \\
\hline
\end{tabular}

Source: Computed from survey data (2020)

Family size: The average family size of the sample households was 4.85 , which is almost in the range of family size per households in our country. The average family size of defaulter's credit users was 5.21 while that of non-defaulter's credit users is 4.57. This shows defaulters households have large member of family size when compared to non-defaulter households. With this, there is statistical mean difference between defaulters and non-defaulters based on family size in the study area (table 4). 
Table 9: Descriptive statistics of family size by repayment status.

\begin{tabular}{lllll}
\hline Family size & Defaulters $(\mathrm{N}=56)$ & Non-defaulters $(\mathrm{N}=83)$ & Total sample $(\mathrm{N}=139$ & $\mathrm{t}$-value \\
\hline Mean & 5.28 & 4.56 & 4.85 & $2.508^{* *}$ \\
Std. Dev. & 1.34 & 1.49 & 1.47 & \\
Minimum & 3 & 2 & 2 & 9 \\
Maximum & 8 & 9 & 9 & \\
\hline
\end{tabular}

** Significant at 5\% probability level

Source: Computed from survey data (2020)

Educational status: Education is a tool to enhance the quality of labor through improving the managerial skill and the tendency to adopt new technologies. According to the survey result, the average years of formal schooling of the sampled respondents were grade 6 . The average educational level of the non-defaulters and defaulters was 6.14 and 2.30 years respectively (Table 5). When we compare the mean educational level of nondefaulters with defaulters the non- defaulters have more education than their counterparts. The t-test, reveals as there is statistically significant mean difference between defaulters and non-defaulters based on education their educational level.

Table 10: Educational level of household head by repayment status

\begin{tabular}{lllll}
\hline Educational level & Defaulters (56) & Non-defaulters (83) & Total sample (N=139 & t-value \\
\hline Mean & 2.30 & 6.14 & 4.59 & $-5.150 * * *$ \\
Std. Dev. & 3.09 & 4.97 & 4.69 & -6 \\
Minimum & 0 & 0 & 12 & \\
Maximum & 12 & 12 & & \\
\hline
\end{tabular}

*** Significant at $1 \%$ probability level

Source: Computed from survey data (2020)

\section{Socio-economic characteristics among defaulters and non-defaulters}

Livestock holding: This means the total livestock owned by the respondents measured by Tropical Livestock Unit (TLU). In the study area livestock are mainly used for ploughing activities and as source of income. Also livestock are used to measure the wealthiest of households in the study area. The average number of livestock owned by respondents in the study area was 4.5 TLU. Non defaulters and defaulters have on average 5.48 and 3.02 TLU livestock respectively. The survey result demonstrated that the mean differences between livestock holding by non-defaulters and defaulters were statistically significant (Table 6). The implication is that livestock is an important asset for farmers not only to perform farm activities such as draught power, to generate income, to secure food and to cover different social, economic and legal expense, but also contribute to secure cash to pay debts.

Table 11: Livestock ownership by loan repayment performance

\begin{tabular}{lllll}
\hline Livestock (TLU) & Defaulters (56) & Non-defaulters (83) & Total sample (139) & t-value \\
\hline Mean & 3.02 & 5.48 & 4.49 & $-6.451 * * *$ \\
Std. Dev. & 1.12 & 3.14 & 2.79 & \\
Minimum & 1.1 & 1.55 & 1.1 & \\
Maximum & 5.79 & 14.56 & 14.56 & \\
\hline
\end{tabular}

*** Significant at $1 \%$ probability level

Source: Computed from survey data (2020)

Participation in off/non-farm activity: Even if farming is the main source of income of respondents in the study area, other source of income will also contribute the borrowers to repay their loan. As per the study result, $41.01 \%$ of the borrowers do not have other source of income whereas about $58.99 \%$ of the borrowers have other sources of income like doing in factories, selling of local drinks and etc. As shown in table 7, about $71.9 \%$ of defaulters and $28.1 \%$ of non-defaulters had no other source of income, whereas $18.29 \%$ of defaulters and $82.7 \%$ of non-defaulters has other source of income in addition to income from farming activities. As per the chi- square test of the result, the effect of availability of other source of income on loan repayment performance is not statistically significant.

Table 12: Participation of household heads in off/non-farm activity by repayment status

\begin{tabular}{|c|c|c|c|c|c|c|c|}
\hline \multirow[t]{2}{*}{ Part. in off/non-farm activity } & \multicolumn{2}{|c|}{ Defaulters (56) } & \multicolumn{2}{|c|}{ Non-defaulters (83) } & \multicolumn{2}{|c|}{ Total sample (139) } & \multirow[t]{2}{*}{$\chi^{2 \text {-value }}$} \\
\hline & No. & $\%$ & No. & $\%$ & No. & $\%$ & \\
\hline Yes & 15 & 26.79 & 67 & 80.72 & 82 & 58.99 & \multirow{2}{*}{$40.213 * * *$} \\
\hline No & 41 & 73.21 & 16 & 19.28 & 57 & 41.01 & \\
\hline
\end{tabular}

*** Significant at $1 \%$ probability level

Source: Computed from survey data (2020)

Purpose of borrowing: Rural households usually borrow money for a wide range of purposes. About 
$50.36 \%$ and $49.64 \%$ of the respondents used for productive purpose like purchase of agricultural inputs and for non-productive purpose like paying for education purpose for their child respectively (Table 8). The survey result demonstrated that the proportion difference between the purpose of borrowing by non-defaulters and defaulters was statistically significant at $1 \%$ level of probability. The implication is that non-defaulter households used the loan for productive purpose instead of consuming it and generated more income which helped to repay their loan.

Table 13: Purpose of borrowing by loan repayment status

\begin{tabular}{llllllll}
\hline \multirow{2}{*}{ Purpose of borrowing } & \multicolumn{2}{l}{ Defaulters $(56)$} & \multicolumn{2}{l}{ Non-defaulters (83) } & \multicolumn{2}{c}{ Total sample (139) } & \multirow{2}{*}{$\chi^{2}$-value } \\
\cline { 2 - 7 } & No. & $\%$ & No. & $\%$ & No. & $\%$ & \\
\hline Productive & 35 & 62.50 & 35 & 42.17 & 70 & 50.36 & \multirow{2}{*}{$5.529 * * *$} \\
Non-productive & 21 & 37.50 & 48 & 57.83 & 69 & 49.64 & \\
\hline
\end{tabular}

*** Significant at $1 \%$ probability level

Source: Computed from survey data (2020)

Land holding of the sample respondents: The land is the essential asset of farmers. The survey result shows as the average size of own cultivated land was nearly 1.44 ha. Non-defaulters and defaulters have an average area of land 1.31 and 1.53 ha respectively. It can be observed from the table (9) that, the total land size owned by non-defaulters was smaller than defaulters. The mean difference between the land holding by defaulters and non-defaulters credit users was insignificant in the study area table (9).

Table 14: Land holding of respondents by loan repayment performance

\begin{tabular}{lllll}
\hline Land size $(\mathrm{ha})$ & Defaulters $(\mathrm{N}=56)$ & Non-defaulters $(\mathrm{N}=83)$ & Total sample $(\mathrm{N}=139$ & $\mathrm{t}$-value \\
\hline Mean & 1.53 & 1.38 & 1.44 & \\
Std. Dev. & 0.81 & 0.72 & 0.76 & 1.415 \\
Minimum & 0.5 & 0.25 & .25 & 4 \\
Maximum & 4 & 3 & 4 &
\end{tabular}

Source: Computed from survey data (2020)

\section{Institutional characteristics of sample households}

Loan size: This is the amount of loan received by the sampled households in the study are. The survey result shows as the average loan size of the respondents in the study area was 4931.65birr. The survey result also revealed that on average Birr 4728.31birrwas borrowed by non-defaulters and defaulters borrowed Birr 5233.04 with no significant mean difference among the groups in the study area (table 10).

Table 15: Amount of loan received by loan repayment status

\begin{tabular}{lllll}
\hline Loan size & Defaulters (56) & Non-defaulters (83) & Total sample $(\mathrm{N}=139$ & t-value \\
\hline Mean & 5233.04 & 4728.31 & 4931.65 & \\
Std. Dev. & 2396.78 & 2230.91 & 2304.03 & 1.270 \\
Minimum & 1500 & 1000 & 1000 & 12000 \\
Maximum & 12000 & 10500 & & \\
\hline
\end{tabular}

Source: Computed from survey data (2020)

Frequency of extension contact: The average extension contact in the study area during the survey year was 6.5 times. The survey result also shows that on average non defaulters got extension contact 6.41 times and defaulters 6.68 times in the study area. The t-test value shows as there was no significant mean difference between the two groups in the study area (table 11).

Table 16: Frequency of extension contact by loan repayment status

\begin{tabular}{lllll}
\hline Extension contact & Defaulters (56) & Non-defaulters (83) & Total sample (139 & t-value \\
\hline Mean & 6.68 & 6.41 & 6.52 & \\
Std. Dev. & 4.03 & 3.77 & 3.87 & 0.401 \\
Minimum & 0 & 1 & 0 & \\
Maximum & 14 & 14 & 14 & \\
\hline
\end{tabular}

Source: Computed from survey data (2020)

Distance from credit source: The distance in minutes that the borrowers traveled on foot to get to a credit source was assessed. Farmers living near lending institution have a location advantage and can contact the lender more easily and frequently than those who live in more distant locations. The average distance of credit source from the home of credit users was 45.35 minutes. In line with this, the average time required to reach lending institutions were 45.71 minutes for non-defaulters and 44.82 minutes for defaulters. The mean difference between the distances covered by non-defaulters and defaulters was statistically insignificant in the study area (table 12). 
Table 17: Distance of credit institution from the resident of the respondent

\begin{tabular}{|c|c|c|c|c|}
\hline $\begin{array}{l}\text { Distance of credit institution } \\
\text { from resident (Min.) }\end{array}$ & Defaulters (56) & Non-defaulters (83) & Total sample (139) & t-value \\
\hline Mean & 44.82 & 45.71 & 45.35 & \multirow{4}{*}{-0.437} \\
\hline Std. Dev. & 10.61 & 12.48 & 11.73 & \\
\hline Minimum & 25 & 25 & 25 & \\
\hline Maximum & 60 & 90 & 90 & \\
\hline
\end{tabular}

Source: Computed from survey data (2020)

Training: Training enables the borrowers to increase their knowledge and improve their skills. As shown in table 3 below, $76(54.68 \%)$ of the sample respondents were received training on loan repayment activities like how they use the loan effectively and efficiently whereas $45.32 \%$ were not taken any training (table 13). Moreover, Chi-square test shows as there is no statistically significant difference between defaulters and nondefaulters in terms of training in the study area.

Table 18: Distribution of training received by loan repayment status of respondents

\begin{tabular}{llllllll}
\hline \multirow{2}{*}{ Training } & \multicolumn{2}{l}{ Defaulters (56) } & \multicolumn{2}{l}{ Non-defaulters $(83)$} & \multicolumn{2}{c}{ Total sample (139) } & \multirow{2}{*}{$\chi 2$-value } \\
\cline { 2 - 6 } & No. & $\%$ & No. & $\%$ & No. & $\%$ & \\
\hline Yes & 28 & 50 & 48 & 57.83 & 76 & 54.68 & \multirow{2}{*}{0.828} \\
No & 28 & 50 & 35 & 42.17 & 63 & 45.32 & \\
\hline
\end{tabular}

Source: Computed from survey data (2020)

\section{Econometric Analysis Results}

The econometric analysis of repayment performance of borrowers used a logit model where the loan repayment$\operatorname{LRP}\left(\mathrm{y}_{\mathrm{i}}\right)=(1$, if the respondent is non-defaulter otherwise 0 , if the borrower is defaulter) is regressed on possible explanatory variables.

\section{Multicollinearity tests}

There are two ways to detect the presence of multicollinearity. These are Variance Inflation Factors (VIF) for association among the continuous explanatory variables and contingency coefficients for dummy variables. As a rule of thumb, VIF greater than 10 or tolerance less than 0.1 is considered as an indicator of multicollinearity (Gujarat, 2003). According to Gujarat, 2005, VIF can be defined as: VIF $\left(\mathrm{X}_{\mathrm{i}}\right)=\frac{1}{1-R i^{2}}$. The VIF values for continuous variables were found to be very small much less than 10 indicating that the absence of multicollinearity between the explanatory variables. The VIF values displayed in (Appendix table 1) have shown that all the continuous explanatory variables have no serious Multicollinearity problem with mean VIF of 1.10 .

The results of the computation of contingency coefficients were computed to check the existence of Multicollinearity problem among the discrete explanatory variables. A contingency coefficient is a measure of the degree of relationship, the association of dependence among variables included in the study. The contingency coefficients are computed as follows:

$$
\mathrm{CC}=\sqrt{\frac{X^{2}}{N-X^{2}}}
$$

Where, $\mathrm{CC}=$ Coefficient of contingency

$\mathrm{X}^{2}=$ Chi-square random variable and

$\mathrm{N}=$ Total sample size.

The decision rule for contingency coefficient is the larger the value of this coefficient, the greater the degree of association. If contingency coefficients approach 1, there is a problem of association between the discrete variables. The values of CC displayed in (Appendix table 2) have shown that all the dummy explanatory variables have no serious Multicollinearity problem.

To handle the heteroskedasticity problem, the robusted standard error were conducted and presented.

\section{Factors affecting loan repayment performance of borrowers}

To identify the determinants of loan repayment performance logit model were employed. The overall significance of the model was significant which shows as the model is good to fit the data. The model result shows, out of twelve independent variables regressed in the model; six variables were found to be statistically significant in affecting the loan repayment performance of the borrowers in the study area (Table 14).

Educational level: The finding of the study shows that educational level of the household head had a positive and significant effect on loan repayment performance of the sampled respondents at less than $1 \%$, significance level. This implies there is a positive association between education and loan repayment. This shows that as the level of education increases, borrowers enhance their ability to access business information, evaluate, and 
understand the information and use it for different activities. This implies that a borrower will likely have greater loan repayment ability when he or she has a higher educational level and vice versa, ceterius paribus. The odds ratio of education shows that, for a one unit increase in educational level of the respondents, the odds of being non-defaulter increase by a factor of 1.35. This result is consistent with the findings of Samuel (2011); Million et al. (2012); Solomon (2013); Fitsum (2014); Pasha and Negese (2014); Firafis (2016) Girma (2018) and Milkessa and Mikir (2020) who found a positive and significant effect of education on the loan repayment performance of the borrowers.

Age: The coefficient of age was significant and positively affected the loan repayment performance of the borrowers at less than $1 \%$ significance level. This shows as there is a positive association between age and loan repayment performance of the borrowers. This implies elders are better than youngsters in adopting technologies, being flexible, accessing education and the like which helps them to accumulate more money to repay the debt. Moreover, the result of the model revealed, for one year increase in the age of the respondents, the odds of being non-defaulter increase by a factor of 1.28. The research findings of Amare (2005), Abebe (2012) and Shaik and Tolosa (2014) also reported as an increase in the income of the borrowers increases the probability of being non-defaulter.

Total livestock ownership: It has positively related to the dependent variable and significant at 5\% probability level. The implication is that livestock are sources of cash in rural Ethiopia and serve as security against crop failure. Farmers who owned more livestock are able to repay their loans even when their crops fail due to natural disaster. Moreover, the result of the model revealed, when livestock ownership of the respondents increased by one TLU, the odds of being non-defaulter increase by a factor of 1.94. This result is consistent with the empirical findings of Worku (2008); Mohammad (2009) and Kebede (2010) which states that having larger number of livestock is positively related to loan repayment performance.

Table 19: Maximum likelihood estimate of a logit model for loan repayment performance

Logistic regression

Log pseudo likelihood $=-33.522786$

\begin{tabular}{|c|c|c|c|c|c|}
\hline Loan repayment & Coef. & Odds Ratio & $\begin{array}{l}\text { Robust } \\
\text { Std.Err. }\end{array}$ & $\mathrm{Z}$ & $\mathrm{P}>\mathrm{Z}$ \\
\hline Age (years) & $0.2518 * * *$ & 1.2864 & 0.0732 & 4.42 & 0.000 \\
\hline Education (grade completed) & $0.2964 * * *$ & 1.3450 & 0.1257 & 3.17 & 0.002 \\
\hline Livestock holding (TLU) & $0.6649 * *$ & 1.9442 & 0.5495 & 2.35 & 0.019 \\
\hline Loan size (birr) & 0.0002 & 1.0002 & 0.0002 & 1.05 & 0.295 \\
\hline Training ( $1=$ if yes, 0 otherwise) & 0.5385 & 1.7134 & 0.9212 & 1.00 & 0.317 \\
\hline Purpose of borrowing & $-1.8523 * *$ & 0.1569 & 0.1280 & -2.27 & 0.023 \\
\hline Family size (No.) & $-0.6748 *$ & 0.5093 & 0.1775 & -1.94 & 0.053 \\
\hline Land size (ha) & -0.4356 & 0.6469 & 0.2463 & -1.14 & 0.253 \\
\hline Frequency of ext. contact (No.) & -0.0508 & 0.9504 & 0.0630 & -0.77 & 0.443 \\
\hline Sex $((1=$ if male, 0 female $)$ & -0.3636 & 0.6952 & 0.4284 & -0.59 & 0.555 \\
\hline Part.off/non-farm activity( $1=$ if yes, 0 otherwise $)$ & $2.5434 * * *$ & 12.7234 & 9.6153 & 3.37 & 0.001 \\
\hline Distance of home from credit source (Min.) & 0.0119 & 1.0120 & 0.0285 & 0.42 & 0.671 \\
\hline cons & $-1.6499 * * *$ & 0.0000 & 0.0001 & -3.23 & 0.001 \\
\hline
\end{tabular}

Note: $* * *, * *$ and $*$ refers to level of significance at $1 \%, 5 \%$ and $10 \%$ respectively.

Source: Model output (2020)

Purpose of borrowing: It is another economic factor that was positively and significantly affected loan repayment performance of smallholder farmers at 5\% probability level. This might be due to the fact that; households who used the loan for productive purpose such as purchased chemical fertilizers, livestock and improved seeds which produce enterprises that would give maximum benefits to the farmer. Each additional unit of available loan for productive purpose, increases odds of being non-defaulter by 0.16 (Table 14). The empirical findings of Mohammad (2009) also came up with similar results in his study on factors affecting on loan repayment performance of farmers.

Family size: The coefficient of family size was negatively related to the respondents' ability to repay their loans and is significant at $10 \%$ significance level. This implies as the number of family member increases the probability of being non-defaulter decreases and vice versa. The binary Logit model result reveals at ceterius paribus, the odd ratio in favor of the non-defaulter decrease by odds of 0.51 as the member of family of the borrowers increased by one child. This result is in line with the findings of Roslon and Karin (2009); Afolabi (2010); Abula et al. (2013) and Girma (2018) and it is in contrast with the study made by Kiliswa \& Bayat (2014); Debeb (2015); Firafis (2014) and Fentahun \& Ahmed, 2018) who reported the positive effect of family 
size on loan repayment performance of the of smallholder farmers.

Participation in off/non-farm activity: This variable affects the loan repayment performance of the respondents positively at $1 \%$ significance level, as it was hypothesized initially. From the binary model result at cetrus paribus the odd ratio in favor of the loan repayment performance increase by odds of 12.7 as the participation in off/non- farm activities shifts from 0 to 1 . This result supports the hypothesis and complies with the results obtained in the descriptive analysis. Similar results were also obtained by Chirwa (1997) and Bekele (2001) in their studies on agricultural credit repayment in Malawi and Ethiopia, respectively.

\subsubsection{Challenges of the institution}

Even though every organization planned to be effective through the implementation of different activities, there are also challenges that hinder the effective functioning of the organization and needs action for further improvement of the organization. Key informant interview was conducted with branch manager and an employee of OCSSC. They explained these challenges as follows.

Lack of adequate man power, high turnover of employees to other organizations, like the private commercial banks, and NGOs and due to this, the officials explore that, the organization is not providing adequate support to its clients. The other problem related they identified is shortage of resource. Loan diversion by borrowers is also another problem as MFIs. Some of loan disbursed was not used for the intended purpose, consequently, the loan become in arrears. The officials also identified low collaboration with other organizations as a problem. For instance, the court does not give timely decision on defaulters which in turn leads to wastage of time as well as money.

From the interview performed with the district branch manager of OCSSC argued that, the most typical challenges faced are; - shortage of supervision and monitoring, poor documentation, insufficient working area, lack of loanable funds for further expansion, not enough employees in the institution mainly in loan department and high turnover of employees' to other organizations are internal problems. In addition to this, some obvious issues like; Occurrence of natural calamities such as drought, pest and diseases infestation of crops and animals reduce farm income, which in turn leads borrowers being default, borrower's unwillingness to repay and political instability are listed as external problems of the institution.

\section{SUMMARY \& RECOMMENDATIONS SUMMARY}

Ethiopia is an agricultural country and has employed more than 83.8 percent of the total population in the agricultural sector. Small farmers are numerically dominant, contributing over 95 percent of the annual production. Yet, this output cannot meet the food requirements of the country's population, let alone serve the needs of farmers. There exists a variety of reasons for this problem; one of the reasons why rural households continue to exist in a vicious cycle of poverty, for long periods is their lack of access to financial services. Limited access to financial service is also aggravated by a poor loan repayment performance record. The increasing default rate is one of the major problems facing lending institutions in the study area. Thus, the main objective of this study was to assess factors affecting loan repayment performance of Oromia credit and saving share company borrowers.

The study was carried out in Ada'a Barga district of west Shewa zone, Ethiopia during 2020. The study focused in this district because of large number of borrowers in this district. Purposive and two stage random sampling were employed to select the sampled respondents. Stratified random sampling was used to stratify credit users and non-users. Then 139 sampled borrowers were selected from credit user by using simple random sampling techniques. Both qualitative and quantitative data were used in the study. Primary and secondary data sources were employed. Descriptive statistics and logit model were used to analyze the data collected from the sample respondents. The descriptive statistics results showed that about 59.71 and 40.29 percent of sample households were non-defaulters and defaulters respectively.

In addition, the inferential statistics results revealed that there were significant differences between defaulters and non-defaulters in Ada'a Barga district with respect to educational level, family size, livestock unit, age, purpose of borrowing, participation in off/non-farm activities.

Moreover, logit model revealed as age, educational level and participation in off/non-farm activities positively and significantly affected loan repayment performance of borrowers at $1 \%$ significance level whereas livestock holding affected positively and significantly at 5\% probability level. In addition family size and purpose of borrowing affected loan repayment performance of borrowers negatively and significantly at $1 \%$ significance level.

From key informant interview made with the manager of OCSSC Ada'a Barga district lack of adequate man power, high turnover of employees to other organizations, like the private commercial banks, and NGOs are the major challenges of the institution. The other problem related they identified is shortage of resource. Loan diversion by borrowers is also another problem as MFIs. Some of loan disbursed was not used for the intended purpose, consequently, the loan become in arrears. The officials also identified low collaboration with other 
organizations as a problem. For instance, the court does not give timely decision on defaulters which in turn leads to wastage of time as well as money.

\section{RECOMMENDATIONS}

Based on the empirical findings, the following recommendations were forwarded to reduce the default rate of OCSSC borrowers.

In the study area, education of household heads had a positive and significant effect on credit repayment performance. Hence, the institution should provide short and long term awareness creation training with particular attention to clients and also include in strategic plan continuous supervision, monitoring, and evaluation system. To reduce the default rate educational level has one of a contributing factor. To minimize the problem of loan utilization and default rate, the government should provide youth education at all kebeles level and facilitates the necessary materials so that farmers can understand financial instructions easily and have better access to information and use the available Credits more efficiently. Then the government, NGOs and the community should contribute their best effort to support the programmer also.

The result of the research indicated that the family size of the household of the borrowers has significant and affected loan repayment performance negatively. The result of the study showed that individuals who have a small family size had better repayment performance than those who have more family size. Therefore, the government should have to provide purposive family planning training for borrowers.

The result of the study indicated that the purpose of borrowing has significant effect on loan repayment performance negatively. So, the development agents should have to give awareness on usage of loan mainly on productive purposes that generate additional income to recover their debt.

To reduce turnover of employee the institution should better to provide incentives like scholarship, bonus and the like. The institution should focus on the repayment challenges which are stated by the borrowers and take corrective actions. To solve the problems of the institution, the main thing might improve the financial capacity of the institution, increase loan size and expand the services.

The government should have to support and strength the integration of OCSSC and Agricultural office to support the poor borrowers.

The econometric results also indicated that borrowers who engaged in off/non-farm activities earned more income and were able to settle their debts in timelier manner, than those who were not engaged in off/non-farm activities. This indicates that, rural development strategies should not only emphasize on increasing agricultural production but simultaneous attention should be given to promoting off/non-farm activities in the rural areas.

In the future, it is better if researchers focus on loan repayment performance of youth fund which is given for MSE by OCSSC which has the highest default problem as I received information from branch manager in the district.

\section{REFERENCES}

Abafita, J. (2003). Microfinance and loan repayment performance: A case study of the Oromia Credit and Savings Share Company (OCSSCO) in Kuyu (Doctoral dissertation, Addis Ababa University).

Abebe, D. (2012). Socioeconomic Factors Influencing Loan Repayment Performance of Microfinance Clients: The Case of Busa Gonofa Microfinance Institution-Ziway Branch, Oromia Regional State; Ethiopia (Doctoral dissertation, St. Mary's University).

Amare B. (2005). Determinants of formal source of credit loan repayment performance of smallholder farmers: The case of North Western Ethiopia, North Gondar. M.Sc. Thesis, Alemaya University, Ethiopia.

Ayalew M. and Lemma Z (2013). Determinants of Loan Repayment Performance of Smallholder Farmers: The Case of Soro Woreda, Hadiya Administrative Zone, Southern Nations, Nationalities and Peoples' Regional State, Ethiopia.

Bekele Hundie, (2001). Factors Influencing the Loan Repayment Performance of Smallholders in Ethiopia. M.Sc. Thesis, Alemaya University, Ethiopia

Bond, P. and Rai, A., (2009) 'Borrower runs', Journal of Development Economics 88 (2009) $185-191$.

Chirwa E. (1997). Econometric Analysis of the Determinants of Agricultural Credit Repayment in Malawi, African Review of Money, Finance and Banking, pp. 107-123

Firafis H.(2014). Determinants of Loan Repayment Performance of Smallholder Farmers: Case study of Harari microfinance, journal of agricultural development and rural development,vol.7(2),pp 56-64.

Firafis H (2016). Credit rationing and repayment performance in the case of Ambo woredaEshet microfinance institution. International Journal of Research in Business Management Vol. 4 (8): 51-68

Girma G (2018). Determinants of Loan Repayment: The Case of Microfinance Institutions in Gedeo Zone, SNNPRS, Ethiopia. Universal Journal of Accounting and Finance 6(3): 108-122

Godquin M., (2004). Microfinance performance in Bangladesh: How to improve the allocation of loans by MFIs. World development journal, 32(11), 1909-1926. 
Kefeni, K. (2018). Determinants of Loan Repayment Performance in Project Financing: A Case Study in Development Bank of Ethiopia (Doctoral Dissertation, St. Mary's University).

Lewis W., (2018) .Effect of Finance Determinants on Loan Repayment among Youth Enterprise Development Fund Board Beneficiaries on Trans Nzoia County, Kenya

Milkessa A. and Mikir M. (2020). Determinants of loan repayment performance of Omo microfinance institution: In the case of Mizan Aman Town, Southwest Ethiopia. Res. J. Business Management, 14: 7-14.

Million S., Nyikal R. and Wangia S., (2012). "Factors Affecting Loan Repayment Performance of Smallholder Farmers in East Hararghe, Ethiopia. "Developing Country Studies, Vol 2, No. 11.

Mohammad R. (2009). Factors affecting on loan repayment performance of farmers in Khorasan-Razavi province of Iran. A Paper Presented to the Conference on International Research on Food Security, Natural Resource Management and Rural Development. Mashhad, Iran.

Nawai N. \& Sharriff M. (2013).Determinants of repayment performance in microfinance programs in Malasyia, Labuan bulletin on international business and finance, 11, 14-29.

Pasha, S. A. M., \& Negese, T. (2014).Performance of loan repayment determinants in Ethiopian micro financeAn analysis. Eurasian Journal of Business and Economics, 7(13), 29-49.

Sengupta, R., \& Aubuchon, C. P. (2008). The microfinance revolution: An overview. Federal Reserve Bank of St. Louis Review, 90

Shaik A. \& Tolosa N. (2014).Performance of Loan Repayment Determinants in Ethiopian Micro Finance.Eurasian Journal of Business and Economics. -7 (13), 29-49.

Sileshi, M., Nyikal, R., \& Wangia, S. (2012). Factors affecting loan repayment performance of smallholder farmers in East Hararghe, Ethiopia. Developing country studies, 2(11), 205-213.

Simkovic M. (2013). Risk-based student loans. Wash. \& Lee L. Rev., 70, 527.

Solomon (2013).Factors influencing formal loan repayment performance of urban women in Tigray, a case study of Dedebit credit and saving institution.M.Sc. Thesis, Mekelle University, Ethiopia.

Worku K. (2008). Analysis of factors influencing the repayment performance of fertilizer credit provided by the farmers' multipurpose service cooperatives. M.Sc. Thesis Presented to Haramaya University, Ethiopia.

Yamane T. I., (1967). Statistics: An Introductory Analysis 2nd Edition. 